\title{
ANOTHER ONE BITES THE DUST: QUALITY CONTROL AND FIRING TECHNOLOGY IN THE PRODUCTION OF MEDIEVAL GREYWARE CERAMICS, CATALONIA, SPAIN
}

\author{
Esther Travé Allepuz ${ }^{1,2}$, Patrick Sean Quinn² and Karen Álvaro Rueda ${ }^{1}$ \\ ${ }^{1}$ Medieval and Post-medieval Research Group, Department of History and Archaeology, University of Barcelona, \\ Montalegre 6, 08001 Barcelona, Spain (esther.trave@ub.edu) \\ ${ }^{2}$ Institute of Archaeology, University College London, 31-34 Gordon Square, London WC1H 0PY, UK \\ (patrick.quinn@ucl.ac.uk)
}

\begin{abstract}
The following study sheds new light on the quality control procedures of ancient potters by comparing cooking vessels exported from the Medieval kiln-site of Cabrera d'Anoia (Barcelona) with 'wasters' that were discarded at source. The firing temperature of examined sherds indicates that only pots subjected to a maximum temperature of $800-850^{\circ} \mathrm{C}$ were offered for sale. The potters at Cabrera d'Anoia appear to have been fully aware of the optimal balance between thermal and physical shock resistance of vessels fired within this range and strived to control firing in order to achieve better products than that of competing workshops.
\end{abstract}

\section{KEYWORDS}

Quality control, pottery wasters, cooking wares, firing, X-ray diffraction, Medieval Catalonia

\section{INTRODUCTION}

The manufacture of pottery and other ceramic products is a complex, multi-step operation that includes processes such as raw material processing, paste preparation, forming, finishing and firing (Rye 1981, Quinn 2013: 151-212). The success of each of these steps has a bearing on whether a particular ceramic object makes it through the entire production sequence and ends up being used for its intended purpose. Potters monitor manufacture at each stage and discard specific vessels if they do not meet quality control criteria (Yxart 2016: 47). Possible defects are numerous and may include sub-standard paste preparation, misshaping during forming (Fig. 1), cracking or exploding during drying; under or over-firing; fusing of vessels with one another or the firing structure; mis-colouration; poor glaze formation; and the running of glaze (Fraser 2005).

What is and is not acceptable in terms of defects is determined by the potter and their individual tolerances, or in the case of specialised production for exchange or sale, by the tastes and needs of the consumer. Certain faults may render vessels unsuitable for their intended purpose, such as major breakage and large cracks or holes in cooking or storage jars. Others may be easily repaired, for example minor fractures or chips. A wide range of other sub-standard pots may still be usable, such as those that are slightly misshaped or those that differ in their degree of firing, colour or finish. These were either exported, maybe at a reduced price (Peña 2007: 33) or discarded by the potter, at source, or perhaps at a later date, if they did not sell.

The topic of quality control in traditional ceramic production is an interesting one that is not often studied archaeologically or ethnographically (Rice 1987, Stark 2003). One issue is that little evidence may remain of ancient pottery production with which to study the process, particularly where ceramics were produced on a small scale, by non-specialists and were open-fired. 
Nevertheless, the nature of 'wasters' associated with kilns and specialised workshops involved in the mass production of ceramics, usually in later periods, can provide important insights into the reasons why they were discarded and hence the quality control criteria applied by potters. Quality control is an important influence on standardisation and variability in ceramic products (Frankel 1994), which is a topic that has been given significantly more attention in the literature (see Rice 1987: 201-204 for a review). The degree of standardisation of the output of a pottery workshop can be controlled by discarding vessels that do not fit a certain definition and may not be marketable (Peña 2007: 34), as well as exercising careful control during all steps in the production sequence (Rice 1987: 201, 203).

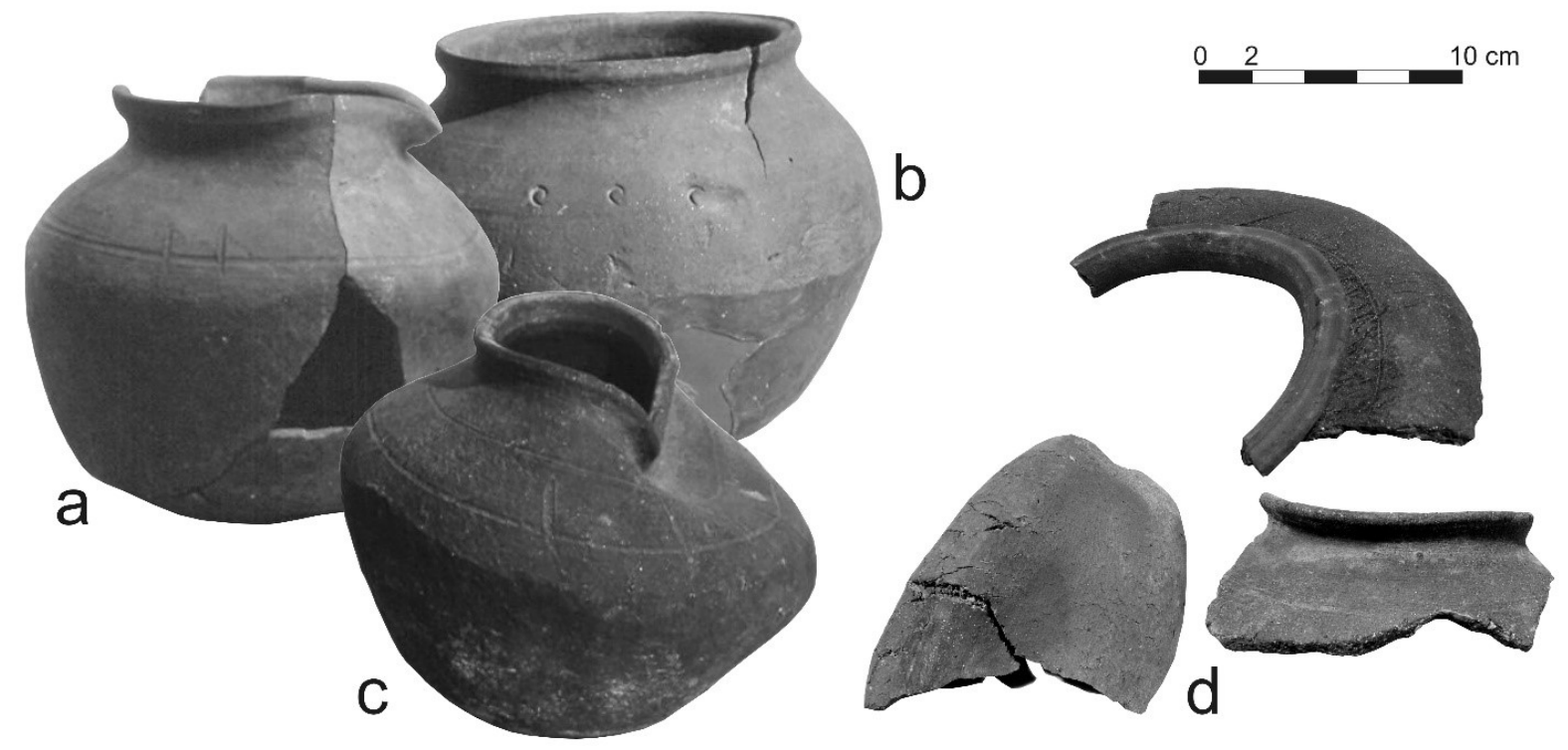

Fig. 1. Physical manufacturing defects within greyware waster sherds from the Medieval greyware pottery workshop of Cabrera d'Anoia. (a) Reconstructed pot broken during kiln collapse, (b) Vessel with cracked rim, (c) Warped pot, (d) Various warped and broken sherds.

Within archaeology the term 'waster' is usually used to refer to vessels that were damaged by the firing process and left behind at the site of production (Rice 1987: 173, 484; Arnold 2000: 366). This includes pots with fatal defects such as significant breakage, as well as those that were overfired and melted (Orton and Hughes 2013: 146). Other objects may have been damaged by the explosion of a neighbouring pot, or the collapse of the kiln structure itself (Peña 2007: 33). A more general term is 'production debris', which in addition to wasters also includes lumps of worked clay (e.g. Peña and McCallum 2009), blobs of melted ceramic material (Pollock et al. 1991), discarded raw materials, spent fuel and the remains of collapsed kilns and other structures. Firing is but one of several stages in the manufacturing process, after which a pot or other ceramic object may be discarded. These include the possible defects listed above, each of which may result in the termination of production and the rejection of the part-made object.

Errors that take place earlier on in the process, before firing, before drying and particularly before forming, may leave no evidence in the archaeological record due to recycling and the poor survival of unfired clay objects. In this respect, broken fired pots that were left in the firing structure or discarded close by represent the most accessible means of accessing the reasons for 
discard at source and the degree of tolerance of the potters in terms of the product they were aiming to achieve. They can also be used to gain an insight into the efficiency of the pottery production process, particularly that of firing. However, it has to be borne in mind that wasters, which may constitute as much as $50-100 \%$ in less successful firings (Rice 1987: 173), can quickly accumulate in large numbers at a workshop and may be moved around from one spot to another. For this reason, it may not always be possible to relate specific wasters to the kiln or part of the workshop in which there were produced (Orton 1970: 346-347). Pots too flawed for immediate sale might be repaired and subsequently used or sold at lower prices for different purposes, such as building material. Another point is that potters may reuse broken pots in subsequent firings, to line or cover the kiln or other structure (Stark 1985: 174-176).

Firing is one of the most important stages of the pottery manufacturing process and may require careful regulation in order to produce pots with the desired attributes. Close control of temperature, soaking time and atmosphere are particularly crucial for the formation of glaze and other decorative finishes. On a more general level, the degree of sintering and vitrification of the clay minerals during firing has an influence on the suitability of a vessel for its intended purpose. This may be the case for cooking ware ceramics, which need to be resistant to the thermal stresses induced by repeated heating and cooling, without cracking or breaking and also able to withstand impact from everyday handling and use (Tite et al. 2001, Müller 2016, Müller et al. 2013). Picon (1995) has studied experimentally the effect of firing on the suitability of pottery for cooking and boiling purposes. According to his findings, pots with a non-calcareous or slightly calcareous coarse clay paste should be fired to an optimal temperature of $700-850^{\circ} \mathrm{C}$. Above this level the fibrillar texture of the clay minerals decomposes as vitrification begins, resulting in increase in strength and rigidity (Rice 1987: 106), which is a desirable feature for pots to resist to mechanical stresses, but with a corresponding reduction in the pots porosity and toughness. In fact, toughness is a much-needed property of cooking vessels, as tougher pots are better to resist crack propagation or micro-cracking due to thermal stresses. In the case of pottery made from a calcareous clay paste, firing below $700^{\circ} \mathrm{C}$ can provide good resistance to thermal shock, however, such pots are susceptible to mechanical shock and may break easily if knocked or dropped. Ancient potters may have been aware of this relationship between the firing temperature and the strength and toughness of cooking pots and attempted to control firing conditions accordingly. They could have assessed temperature using the colour of the pots during firing (Rice 1987: 157$158,166)$ and the degree of sintering and vitrification of fired vessels after firing by using their hardness and the 'ring' that they made when lightly struck. These latter criteria may have been used to discard pots that were physically well made in terms of their size, shape and decoration, but not fired within the desired range.

In the present study, the nature of Medieval greyware ceramics from the workshop of Cabrera d'Anoia in Catalonia, Spain are used to test the above idea and determine whether potters at the site assessed their fired products pots using such criteria, selecting only those with specific firing characteristics for export and sale. Sherds of greyware cooking vessels are one of the most abundant artefacts at sites in Medieval Catalonia and adjacent areas (Fig. 2). These coarse, undecorated, reduction-fired pots evolved from Late Roman cooking wares and went on to dominate the ceramic record of the 5th-14th centuries AD (González 1997; Vigil-Escalera and Quirós 2016). As such they represent an important means of investigating aspects of Medieval life in the region, including craft technology, trade, consumption and domestic activities.

The excavation of several kiln sites (Travé 2017, Cantoni and Folch 2015, Travé and Padilla 2013) and the scientific analysis of their contents has led to a good understanding of the nature of Medieval Catalonian greyware production and its evolution over time (Travé et al. 2014). One 
such site is Cabrera d'Anoia (Fig. 2) (Padilla et al. 2008; Padilla and Travé 2010), where a combination of petrographic and geochemical characterisation permitted the establishment of several 'control groups' that are characteristic of this workshop (Travé et al. 2014). By also detecting these among greyware pottery sherds from numerous consumption contexts in Catalonia, it has been possible to examine the nature of the rural markets that were served by this site and other regional production centres such as Casampons, Piera and Quart (Travé et al. 2016), as well as addressing issues such as competition and political influences on distribution and trade (Fig. 2).

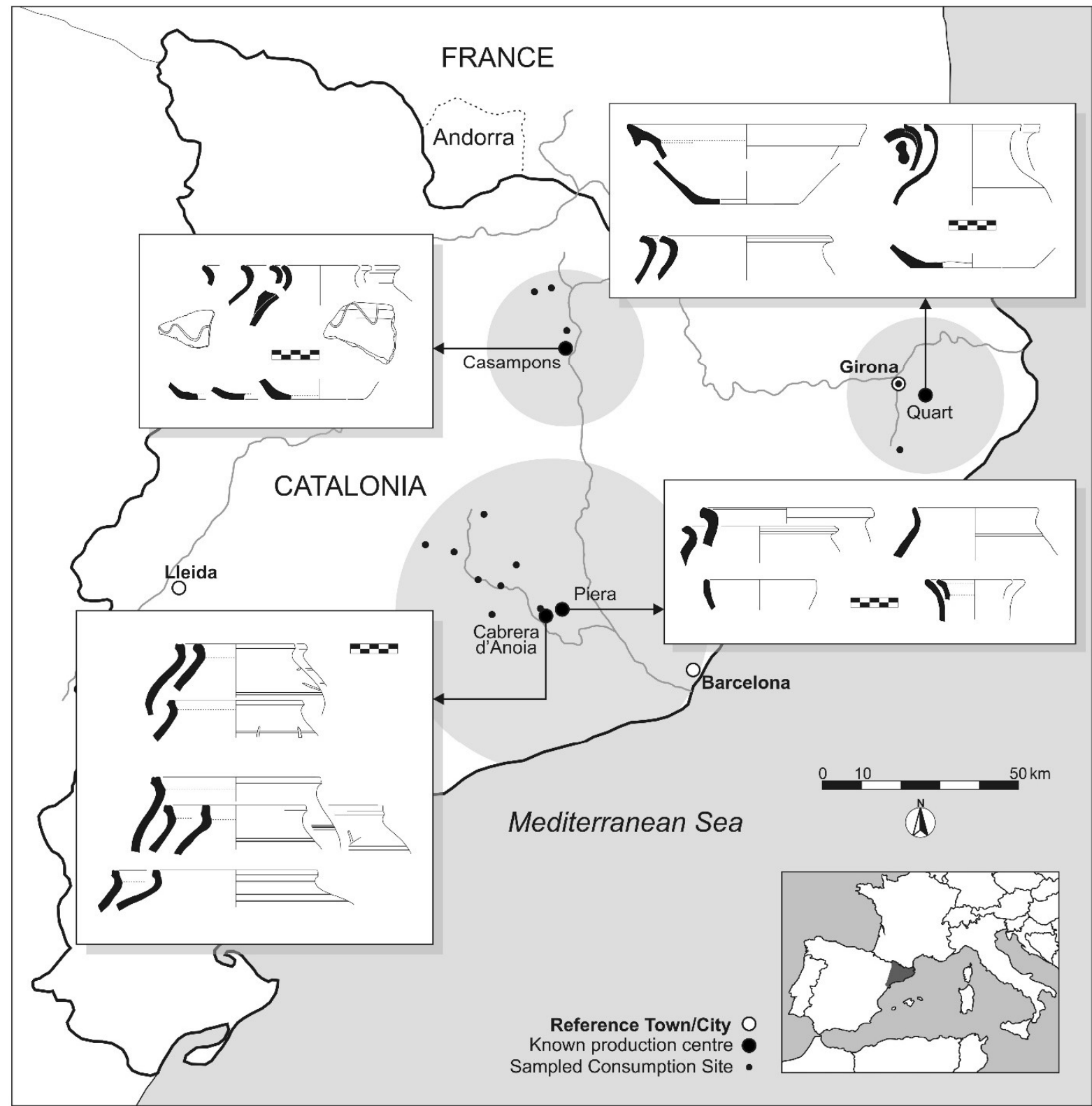

Fig. 2. Location of key greyware pottery workshops in Medieval Catalonia (large dots) including the kiln site of Cabrera d'Anoia (Travé et al. 2014). The products of this and other production centres were identified at various locations across the region (small dots) using petrographic and geochemical data in order to study ceramic distribution, trade and the individual markets (grey zones) (Travé et al. 2016). The vessel shapes produced at each of the workshops is illustrated. 
In positively identifying the presence of exported goods from a specific workshop, the opportunity arises to compare these with waster sherds left behind at the kiln site. By examining the distributed products in the context of the failed and rejected pieces that did not make it, it is possible to address the topics of quality control and firing efficiency in the production of Medieval pottery. This has been carried out in the present paper by examining the morphological characteristics of both the wasters and the exported pots from Cabrera d'Anoia, as well as interpreting their firing conditions. The latter has been determined through the study of their mineralogical composition by X-ray diffraction and thin section petrography. This data has been used to determine whether Medieval potters at the site assessed their products based on temperature and degree of firing, selecting only those with specific favourable characteristics for export and sale. The relative quality control strategies of Cabrera d'Anoia and other competing Medieval greyware sites in Catalonia, whose products have also been identified at numerous rural settlements within the region (Travé et al. 2016), are also compared.

\section{MATERIALS AND METHODS}

A total of 5000 wasters of greyware pottery from the 11-14th century AD operation of the workshop Cabrera de Anoia were studied by eye, noting any physical defects and classifying these using recognised criteria such as blistering, coring, cracking, warping, underfiring, uneven firing or vitrification (e.g. Casey and Lowe 2011: appendix 4.3, Fraser 2005). The shape, wall thickness, diameter, and colour of the parent vessel from which the sherds originated were also recorded, where possible. The vast majority (c. 95\%) of the vessels produced at the site in Medieval times were a type of spherical boiling pot with a diameter of c. $20 \mathrm{~cm}$, referred to as an 'olla' (Fig. 1 and 2). Other forms such as casseroles, washbasins and water jars were also present, but in much smaller numbers. Most of 'ollae' exhibited 5 to $8 \mathrm{~cm}$ thick walls are were made of non-tempered coarse pastes with naturally-occurring silt to coarse sand-sized inclusions of polycrystalline quartz, weathered plagioclase and alkali feldspar, biotite and small intact rock fragments composed of two or more of these minerals (Travé et al. 2014: 401).

According to their macroscopic features and typological classification, a representative selection of 99 sherds from Cabrera d'Anoia that were previously analysed compositionally via thin section petrography and bulk geochemistry (Travé et al. 2014) were then characterised mineralogically using X-ray diffraction (XRD) in order to assess their degree and temperature of firing. This approach to 'archaeothermometry' (Rice 1987: 426-435) relies on the detection of mineral 'phases' that form or are lost at specific temperatures during the firing of ceramics (Quinn and Benzonelli, 2018) and makes use of 'bar diagrams' that document the firing sequence of a typical pot (e.g. Küpfer and Maggetti 1978, Maggetti 1982, Maritan 2004, Maritan et al. 2006, Maritan et al. 2007) (Fig. 3). X-ray diffraction was performed at the Scientific and Technological Centres of the University of Barcelona (CCiTUB) using a Siemens D-500 X-ray diffractometer. Small (c. $1 \mathrm{~g}$ ) subsamples from each sherd were ground to a fine powder and dried at $110^{\circ} \mathrm{C}$ for 12 hours after the removal of the surface layer with a tungsten carbide drill. The powdered samples were spread and flattened on a standard XRD well slide and bombarded with $\mathrm{Cu}-\alpha$ radiation $(\lambda=1.5406 \AA)$ with a graphite diffracted beam monochromator and a power of $1.2 \mathrm{~kW}(40 \mathrm{kV}, 30 \mathrm{~mA})$. The diffracted X-rays were measured in the range $4.0-70.0^{\circ} 2 \Theta$ using $0.05^{\circ}$ step width, a speed of $1.0^{\circ}$ per minute in continuous scanning mode. The resulting diffractograms were analysed using the Panalytical HighScore-Plus software (Degen et al. 2014) in order to identify the peaks or reflectance. These were interpreted in terms of the minerals present in the samples using the International Centre for Diffraction Data-Joint Committee of 
Power Diffraction Standards, 2006 (ICDD-JCPDS) database. The mineralogical assemblages detected in each of the 99 analysed sherds were compared to the body of literature that exists on XRD ceramic archaeothermometry (Küpfer and Maggetti 1978, Maggetti 1982, Sedmale et al. 1990, Cultrone et al. 2001, Maritan 2004, Maritan et al. 2006, 2007, Nodari et al. 2007) in order to assess their relative firing conditions and assign an approximate temperature range. It was not possible to fire representative raw materials used by the Medieval potters at Cabrera de Anoia as the sources of these are not known and the excavated ancient workshop is no longer accessible.

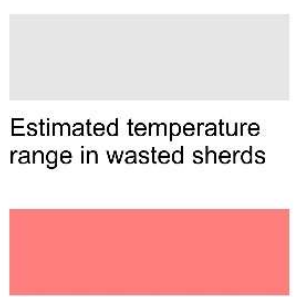

Estimated temperature range in successful pots

Mineral abbreviations
Cal - Calcite
$\mathrm{Di}$ - Diopside
$\mathrm{Hc}$ - Hercynite
Hem - Hematite
Ilt - Illite
Kfs - Potassium Feldspar
Mgh - Maghemite
Mul - Mullite
PI - Plagioclase
Qz - Quartz

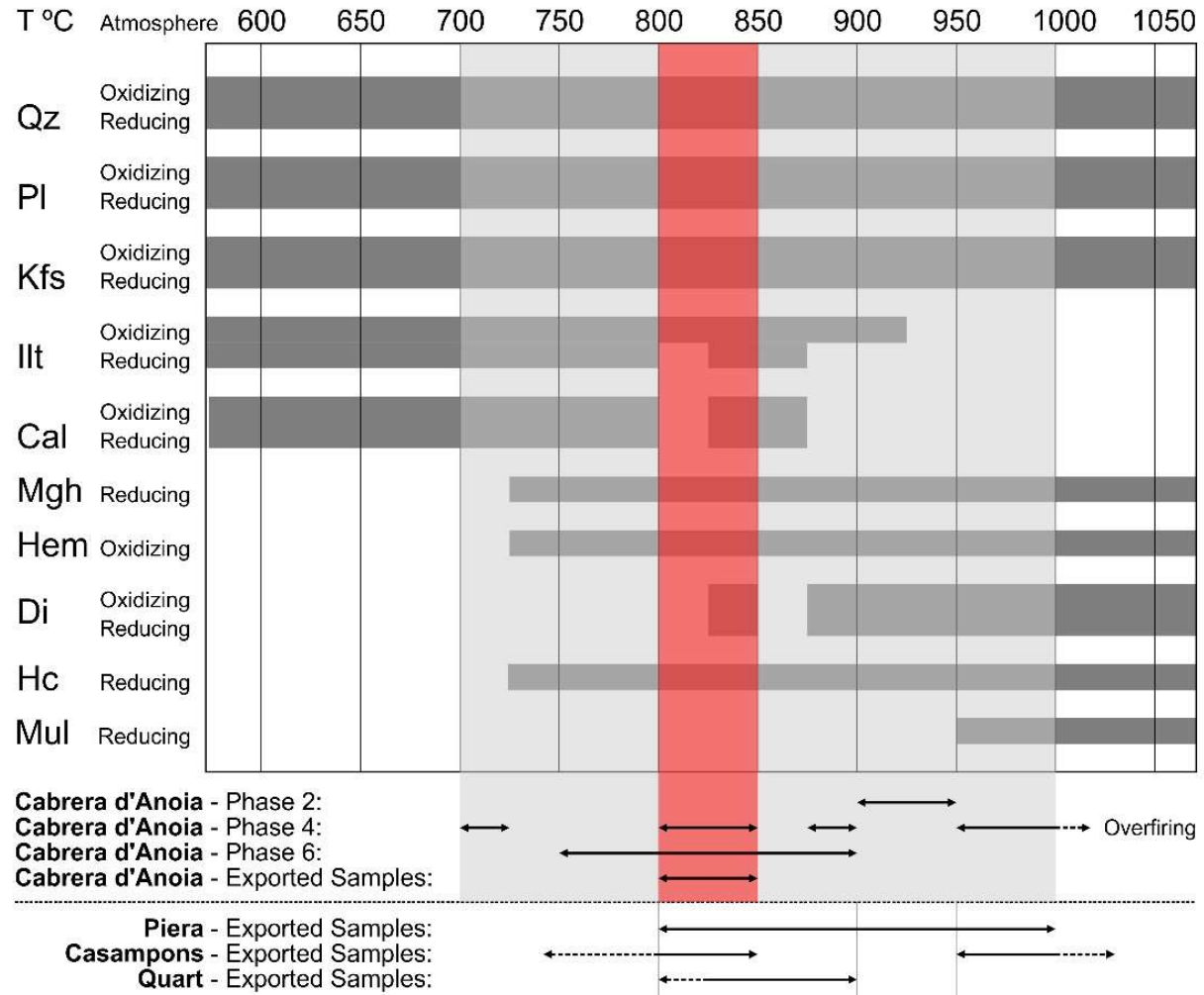

Fig. 3. Bar diagram of the stability of minerals during the firing of ceramics (Redrawn from Maritan et al. 2006: figs. 4 and 5: 6-7), with the interpreted firing temperature range for wasters and exported ceramics from Cabrera d'Anoia in this study. Mineral abbreviations according to Whitney and Evans (2010).

Observation of the 'optical activity' of the clay matrix of each sherd was made in thin section under the petrographic microscope in crossed polars (XP). Although optical activity may be obscured by heavy reduction, this can be used to estimate the equivalent firing temperature of pottery (Quinn 2013: 190-191). Selected sherds were also analysed under the scanning electron microscope (SEM) in fresh-fracture. The state of vitrification of their clay matrices was noted and compared to published studies (Faber et al. 2009, Maniatis and Tite 1975, Tite and Maniatis $1975 \mathrm{a}, 1975 \mathrm{~b})$ to provide an additional cross-check on the archaeothermometric interpretation determined via XRD.

Macroscopic and mineralogical analysis was also performed on a total of 37 contemporaneous greyware sherds excavated from consumption contexts at various archaeological sites in Catalonia (Fig. 2). These were chosen based on the provenance study of Travé et al. (2016), 
which examined the ceramic distribution patterns of Cabrera d'Anoia and other kiln sites in the region. A total of 19 sherds were positively assigned to Cabrera d'Anoia using the petrographic and geochemical reference groups established for this workshop in the earlier study of Travé et al. (2014). In the absence of control groups for other Catalan greyware kiln sites, the probable origins of the remaining sherds were investigated via comparisons between their petrographic composition and the bedrock geology of the region (Travé et al. 2016). This revealed an additional 18 greyware sherds that could be confidently traced to the three workshops of Casampons, Piera and Quart (Fig. 2). All 37 provenanced sherds, which derived from ollas, were examined for possible defects and studied morphometrically. They were subjected to detailed XRD characterisation in order to determine their firing temperatures using the methodology described above. Analysis was performed at the Wolfson Material Culture and Archaeological Science (MCAS) laboratories of the Institute of Archaeology, University College London, using a Rigaku MiniFlex 600 Benchtop X-ray Diffractometer with power of $0.6 \mathrm{~kW}(40 \mathrm{kV}, 15 \mathrm{~mA})$. Measurement was conducted between 3.0-90.0 $2 \Theta$ using $0.02^{\circ}$ step width, a speed of $10.0^{\circ}$ per minute in continuous scanning mode.

Detailed comparisons were made between the firing defects, macroscopic characteristics and estimated firing temperature of the 99 waster sherds from Cabrera d'Anoia and the 19 exported pieces from this workshop, in order to examine firing efficiency, quality control and discard. In the absence of data on waster sherds from the other kiln sites of Casampons, Piera and Quart, a comparison was performed with the defects and firing conditions of the exported Cabrera d'Anoia ceramics. This provided a means of assessing relative the degree of quality control exercised by potters at these centres. Finally, the temperature ranges of all 99 waster sherds and 37 consumed ceramic pieces were used to test the suspected relationship between firing, material properties and suitability of pottery for cooking purposes proposed by Picon (1995) and others.

\section{RESULTS}

\section{Cabrera d'Anoia waster sherds}

Visual examination of the 5000 waster specimens from Cabrera d'Anoia revealed that a surprisingly small proportion (1\%) exhibited physical imperfections that could have resulted in their discard. These included over-firing symptoms such as warping, fusing and bloating (Fig. 1). The vast majority (99\%) of the ceramic specimens were broken sherds, however, it was not possible to determine whether fragmentation occurred during firing or afterwards, due to the dumping of wasted material into the abandoned kilns. Most of the studied samples have a consistent dull grey colour that is characteristic of Medieval greyware, though some variation exists, with specimens ranging from whitish pale grey to bluish dark grey. A small proportion of samples exhibit slightly reddish or brownish colour that is suggestive of a more oxygen-rich firing atmosphere.

Thin section petrography and XRD reveal that all 99 greyware waster sherds from Cabrera d'Anoia contain quartz, plagioclase feldspar and potassium feldspar. These three minerals are stable up to high temperatures during the firing of ceramics (Küpfer and Maggetti 1978, Maggetti 1982, Maritan 2004, Maritan et al. 2006, 2007, Nodari et al. 2007). Feldspars begin to melt around $1150^{\circ} \mathrm{C}$ (Cardew 1969, Rice 1987: 104), suggesting that none of the ceramics reached this temperature, at least for a sustained length of time. The iron oxide mineral maghemite begins to nucleate during the firing of ceramics above $750^{\circ} \mathrm{C}$ under reducing conditions (Maritan 2004). Its presence/absence can therefore be used to distinguish between samples fired above and below this level among the analysed greyware sherds (Fig. 4). 

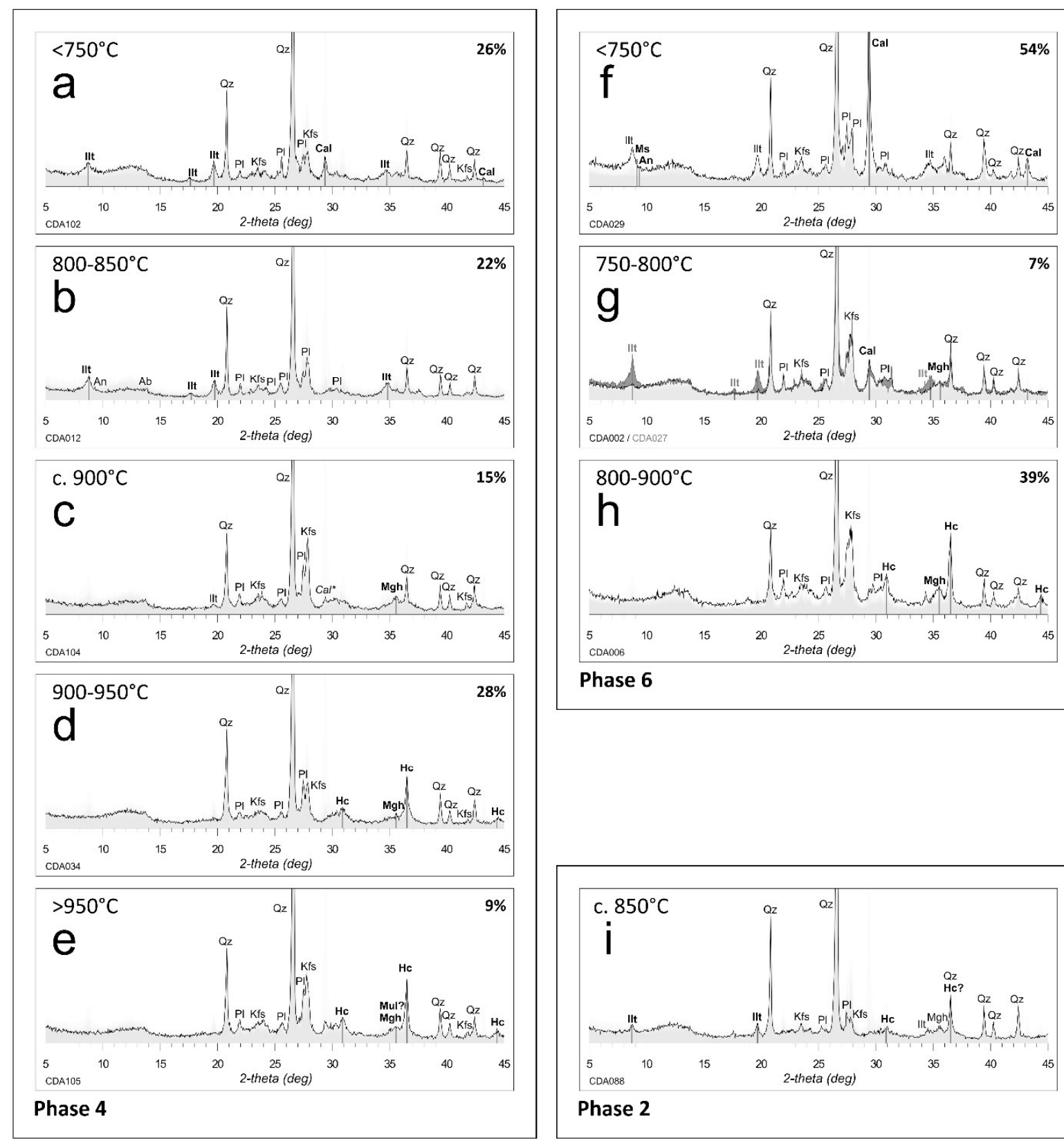

Phase 6

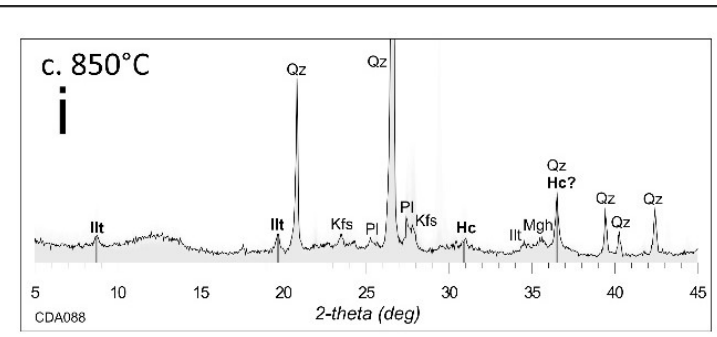

Phase 2

Fig. 4. Interpreted diffractograms of Medieval greyware waster sherds found at the kiln site of Cabrera d'Anoia, with estimated firing temperature. The percentage of samples included in each mineral fabric is indicated for each diffractogram above right. Mineral abbreviations according to Whitney and Evans (2010).

The presence/absence of maghemite, along with the presence/absence of calcite has been used to discriminate samples subjected to $750-800^{\circ} \mathrm{C}$ from those fired $>800^{\circ} \mathrm{C}$ (Fig. 4). The temperature at which calcite dissociates during firing may vary (Rice 1987: 103), however, several authors have reported this to be at or around $800^{\circ} \mathrm{C}$ (Küpfer and Maggetti 1978, Cultrone et al. 2001, Maritan 2004). Illite appears to have been the dominant clay mineral in all or most of the analysed greyware ceramics (Pradell 1992). The point at which its crystalline structure is irreversibly changed and it can no longer be detected by XRD is an important indicator for 
archaeothermometry. This may start at as low as $850^{\circ} \mathrm{C}$ (Nodari et al. 2007) or $800^{\circ} \mathrm{C}$ (Cultrone et al. 2001, Maritan 2004) and can break down earlier in a reducing atmosphere compared to oxidised firing (Maritan 2004). The absence of illite peaks in the diffractograms of certain sherds (Fig. 4c-e) correlates well with a low degree of optical activity of the clay matrix, which is thought to be lost between $800-850^{\circ} \mathrm{C}$ in earthenware pottery (Quinn 2013: 190-191). Hercynite typically appears between $850-900^{\circ} \mathrm{C}$ during the firing of pottery (Maritan et al. 2006), so the detection of this mineral in some samples via XRD is therefore a useful high temperature indicator. Another 'neophase' that is indicative of high firing is mullite, which is present in certain sherds with strong hercynite peaks and no illite and calcite (Fig. 4e). This needle-like mineral can form from muscovite at $800^{\circ} \mathrm{C}$ (Cultrone et al. 2001) or may appear at $1050-1100^{\circ} \mathrm{C}$ from the alteration of spinel (Rice 1987: 104, Sedmale et al. 1990). Given that muscovite was present in the diffractograms of some samples as well as in thin section, and spinel is rare, the presence of mullite is likely to indicate the lower of these two transformations.

Based upon the above indicator minerals and associations, the 99 greyware waster sherds from Cabrera d'Anoia exhibit a fairly wide range of firing temperatures from $750^{\circ} \mathrm{C}$ or less to greater than $950^{\circ} \mathrm{C}$ (Fig. 4). There appear to be differences in the range of temperatures to which the wasted sherds were subjected between the various phases of production at the workshop. During phase 4 , when the workshop is thought to have been at its peak, most of the analysed sherds were fired within a narrow range of c. $850-900^{\circ} \mathrm{C}$ (Fig. $4 \mathrm{~b}-\mathrm{c}$ ), with relatively few pots fired above and below this (Fig. 4a and 4d-e). Sherds from Phase 6a contain many samples fired $<750^{\circ} \mathrm{C}$ (Fig. $4 \mathrm{f})$, due to the presence of a collapsed kiln from this period that contained partially fired pots.

\section{Exported greyware pottery}

The 19 exported sherds from Catalan consumption sites that were assigned to Cabrera d'Anoia based on their composition (Travé et al. 2016) do not contain any physical production defects such as misshaping, cracking, warping, fusing or bloating. By applying the above archaeothermometric criteria it is possible to determine their probable firing temperature range. This reveals that the majority $(65 \%)$ of the sherds were fired between $800-850^{\circ} \mathrm{C}$, due to the presence of a moderate illite peak, an absence of primary calcite and an absence of high temperature minerals such as hercynite, mullite and spinel (Fig. 5b). These 13 sherds can be attributed to Phase 4 of the workshop based upon a comparison of their petrographic and geochemical composition with the Cabrera d'Anoia reference groups (Travé et al. 2014). One exported Phase 4 sample may have been fired slightly below this temperature given its larger illite peak (Fig. 5a). The rest of the of exported Cabrera d'Anoia sherds, which were attributed compositionally to Phases 2 and 6 of the workshop, contained mineralogical assemblages that are indicative of higher firing temperatures. These include a sherd with maghemite related to Phase 6 (Fig. 5c) and two from Phases 2 and 6 containing maghemite and possible (Fig. 5d), or probable hercynite (Fig. 5e). In general the reconstructed firing temperature range of the 19 sherds is narrower than that of the contemporaneous waster pottery analysed from Cabrera d'Anoia itself, especially when one considers the main phase of operation of the kiln site.

Examination of the additional 18 exported greyware sherds that could be confidently traced to the other Catalan workshops of Casampons, Piera and Quart (Travé et al. 2016) revealed that they too exhibited no physical production defects. Their optical activity, SEM microstructure (Travé 2018: 78-82) and their mineralogical assemblages determined by XRD suggest that they were subjected to a wider range of firing temperatures than the 19 sherds assigned to Cabrera d'Anoia. Samples originating from a workshop near Piera (Fig. 2) include lower-fired $\left(<850^{\circ} \mathrm{C}\right)$ examples in which maghemite is absent (Fig. 5f), a sample with illite and maghemite (Fig. 5g) and sherds 
with hercynite and no illite fired at higher firing temperatures $\left(>950^{\circ} \mathrm{C}\right)($ Fig. $5 \mathrm{i})$. Sherds from the workshop of Casampons, include examples fired $<850^{\circ} \mathrm{C}$ (Fig. 5f) as well as $>950^{\circ} \mathrm{C}$ (Fig. 5i). Finally, the greyware sherds attributed to the area of Quart (Fig. 2), though few in number in the analysed dataset, mostly appear to have been fired $<850^{\circ} \mathrm{C}$ (Fig. 5f), but one sample may have been subjected to temperatures of $875-900^{\circ} \mathrm{C}$ due to the absence of illite or high temperature minerals (Fig. 5h).
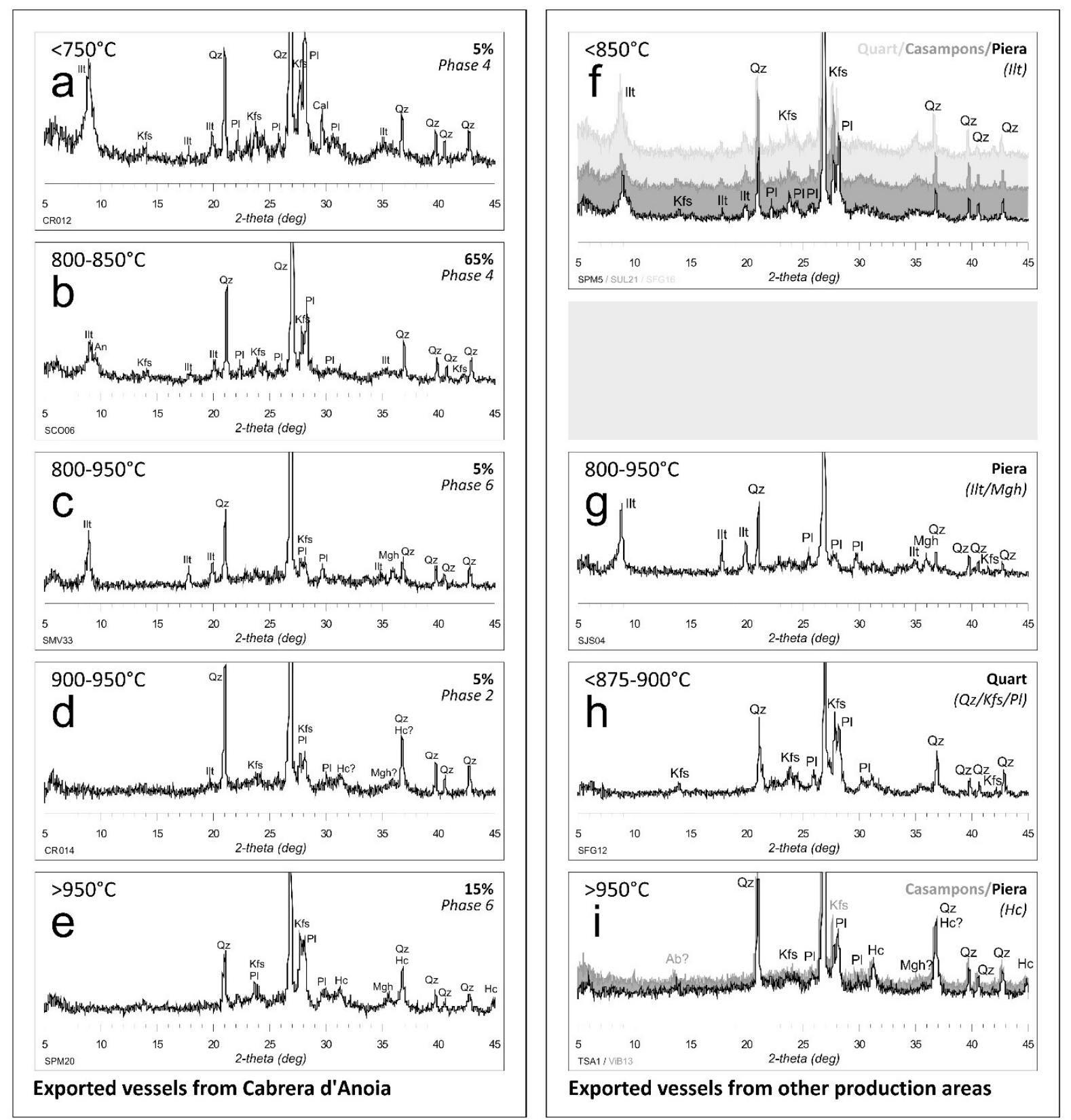

Fig. 5. X-ray diffractograms of Medieval greyware pottery sherds exported from the workshop of Cabrera d'Anoia (left) and potentially from the workshops of Piera, Casampons and Quart (right) with identified mineral phases and estimated firing temperature. Mineral abbreviations according to Whitney and Evans (2010). 


\section{DISCUSSION}

Visual examination of 5000 greyware waster sherds from the workshop of Cabrera d'Anoia revealed very few physical production defects. This suggests that the Medieval potters working at this site maintained sufficient control over the firing process in order to prevent significant melting, warping, fusing and other errors that result from over-firing. The existence of large numbers of waster sherds at the long-lived workshop, which can be found in the abandoned kilns, means that pottery failure did occur during firing and/or that some sort of quality control was exercised after firing. A proportion of the broken, but otherwise undamaged sherds could have been discarded due to the explosion of pots or their sudden movement, both of which are processes that are known to result in fragmentation during firing in traditional pottery production (Basart 2016: 74-75). The kilns at Cabrera d'Anoia were cut into a natural rock feature by excavating relatively soft weathered granodiorite beneath a harder travertine layer (Travé et al. 2014). After several successive firings this ceiling would collapse, signalling the end of the kilns use-life, after which the potters would construct another one further along the outcrop. The failure of the kiln structures in this way is likely to have resulted in vessel breakage, if this took place during or shortly after the firing process, while the kiln was full. It is therefore possible that some of the fragmented waster sherds were left behind for this reason.

An additional reason for discard, and one which may be revealed by the data in this study, is the quality control of successfully fired, un-broken pots at source, based on one or more nonmorphological criteria. Two possible characteristics via which the fired pots could have been assessed are their final colour after cooling and their degree of firing. Most utilitarian unglazed cooking pottery that was produced and used throughout Catalonia during the Medieval period has a dull grey colour (Padilla 1984, González 1997) and only a few of the waster sherds from Cabrera d'Anoia deviate from this norm. This indicates that the potters were able to control the redox atmosphere of their kilns fairly well, which was achieved by closing the structure at the end of the firing to restrict the availability of free oxygen and reduce iron in the ceramic body (Travé et al. 2014). The exported products of the workshop, studied from consumption sites in the present paper exhibit a similar range of grey colours to the waster sherds, with only very occasional more oxidised specimens. This seems to suggest that the pots' final colour after firing may not have been an important criterion that was used to filter the products of the workshop of Cabrera d'Anoia.

Turning to the temperature of firing of the waster sherds and their relationship to that of the exported sherds from this site, our dataset appears to indicate evidence for the discard of successful pottery vessels based upon their individual degree of firing. The 99 analysed wasters from Cabrera d'Anoia generally have a wider range of interpreted firing temperature, based on the results of XRD, thin section petrography and SEM, than the 19 sherds of pottery exported from the workshop to various consumption sites (Fig. 3). This is most clear in Phase 4, in the mid thirteenth century AD, when production was at its peak. During this period the potters working at Cabrera d'Anoia were able to fire pottery within a restricted temperature range of $800-900^{\circ} \mathrm{C}$, yet appear to have only retained and exported those successful pots fired between $800-850^{\circ} \mathrm{C}$, discarding at source any vessels fired $>850^{\circ} \mathrm{C}$. This clear difference, along with the higher proportion of physical defects among the wasters compared to the exported sherds, may represent evidence of quality control. It seems to indicate a conscious decision on the part of the craftsmen working at the site, to maintain a certain standard in the manufactured products of Cabrera d'Anoia that were subsequently offered for exchange or sale. 
So why did the potters of Cabrera d'Anoia, and their customers, seek vessels fired within this restricted temperature range? What were the advantages, functional or otherwise, of cooking pots subjected to these conditions? In order to answer this question it is necessary to examine the material properties of coarseware ceramics fired to different temperatures and the advantages or disadvantages of these for utilitarian cooking purposes. A significant body of literature exists on this topic, most of which is based on experimental laboratory studies (see Müller 2016 for a review). The key parameters that are of relevance to such a discussion are thermal shock resistance, thermal conductivity, fracture strength and toughness.

Thermal shock resistance is the ability of a pot to withstand the stresses from rapid repeated heating and cooling (Müller et al. 2013), for example during cooking and boiling. These result from the differential expansion and contraction of the clay matrix and the various inclusions that make up the ceramic's fabric, as well as temperature gradients between the core and outer surfaces of the pot. Several interrelated factors affect a ceramic vessel's thermal shock resistance, such as the size, amount and type of intrinsic inclusions and temper, the extent of vitrification of the clay matrix and the effect that these have on the initiation and propagation of fractures (Tite $e t$ al. 2001, Müller et al. 2013). It is the development of fractures due to thermal stresses and their propagation through the wall of a pot that result in its failure during cooking. Increasing the strength of the ceramic fabric reduces the likelihood of fractures forming. This can be achieved by increasing firing temperature until the vessel develops a harder, more vitrified microstructure. Once initiated, the growth of fractures is slower in non-vitrified ceramics, which have greater toughness due to their stable crack propagation mode (Kilikoglou et al. 1998, Müller et al. 2010).

Inclusions can have either a negative or a positive effect on thermal shock resistance in cooking pots depending on their composition and size. Those with a different thermal expansion coefficient than the clay matrix can produce stresses during heating and cooling (Rye 1976), which can lead to fracture development. Once initiated, however, fractures can be arrested or deflected by non-plastic inclusions (Müller 2016). For this reason, coarse more inclusion-rich ceramics have greater toughness than finer pots fired to the same temperature (Tite et al. 2001). All analysed ceramics from the workshop of Cabrera d'Anoia contain abundant, generally coarse inclusions dominated by the mineral quartz and to a lesser extent, feldspar (Travé et al. 2014). Quartz has a higher thermal expansion coefficient than fired clay (Rye 1976) and may therefore create thermal stresses during heating and cooling. However, it has been proposed that this process creates zones of 'microdamage' in the clay matrix around the quartz grains, which increase the ceramic's toughness (Kilikoglou et al. 1995).

In addition to being able to withstand thermal shock, utilitarian cooking vessels need to be able to cope with the physical stresses of everyday use, without loosing their contents. They may be knocked while lifting and moving, and impacted by cooking implements during stirring and serving. As with resistance to the stresses caused by thermal shock, two critical factors are the ceramic's strength and toughness. The former is greater in higher fired, finer ceramics and reduces the likelihood of cracks forming during impact and load, whereas the latter, which prevents cracks from propagating, is greater in non-vitrified pottery and increases with the addition of temper (Tite et al. 2001). For cooking pots, it is advisable to strike a balance between strength and toughness, so that the vessel is able to support the weight of its contents and survive a certain level of impact without cracking, but also be able to accommodate physical stress through the development of fractures and the dissipation of energy along them. This idea is emphasised in the work of Picon (1995), who studied experimentally the suitability of pots for cooking purposes in relation to their composition and firing temperature. By plotting the pottery exported from Cabrera d'Anoia on his three-pole model (Fig. 7), it can be seen that they have 
moderate strength and high toughness due to their well-sintered, but non-vitrified clay matrix. Comparable pots fired to a lower temperature will have been weaker to withstand everyday use compared to those exported from Cabrera d'Anoia and those fired to the point of vitrification would have been too brittle and also broken easily. Picon's (1995) model also predicts that the products of Cabrera d'Anoia found at consumption sites had good thermal shock resistance as they are both inclusion-rich and have the correct balance between strength and toughness. In addition, the presence of quartz inclusions may have produced the advantageous fracture zones in the surrounding matrix that were proposed by Kilikoglou et al. (1995).

The good agreement between the findings of the present study and the empirical studies of Picon (1995) (Fig. 6) and others, discussed above, seems to suggest that the discard at source of pottery fired above and below a specific temperature range at the greyware ceramic workshop of Cabrera d'Anoia represents a conscious effort on the part of the potters to control the quality of their products and supply their customers with vessels that are most suited to the material demands of everyday utilitarian use for cooking and boiling. This would imply that they had a good appreciation of what made a good cooking pot, particularly how firing vessels to a specific temperature or degree of vitrification optimised their performance. This is likely to have been learned through repeated manufacture and use, as well as via feedback from customers, which probably contributed to the development of a solid tradition of production. The degree of firing of the vessels could have been assessed based upon their hardness and ring after firing. It is only by characterising in detail the composition and probable firing temperature of pots from this workshop (Travé et al. 2014), by using this information to identify the exported products of the kiln site (Travé et al. 2016) and comparing the conditions to which the two sets of material were subjected, that it has been possible to reveal this interesting pattern of quality control in Medieval ceramic production.
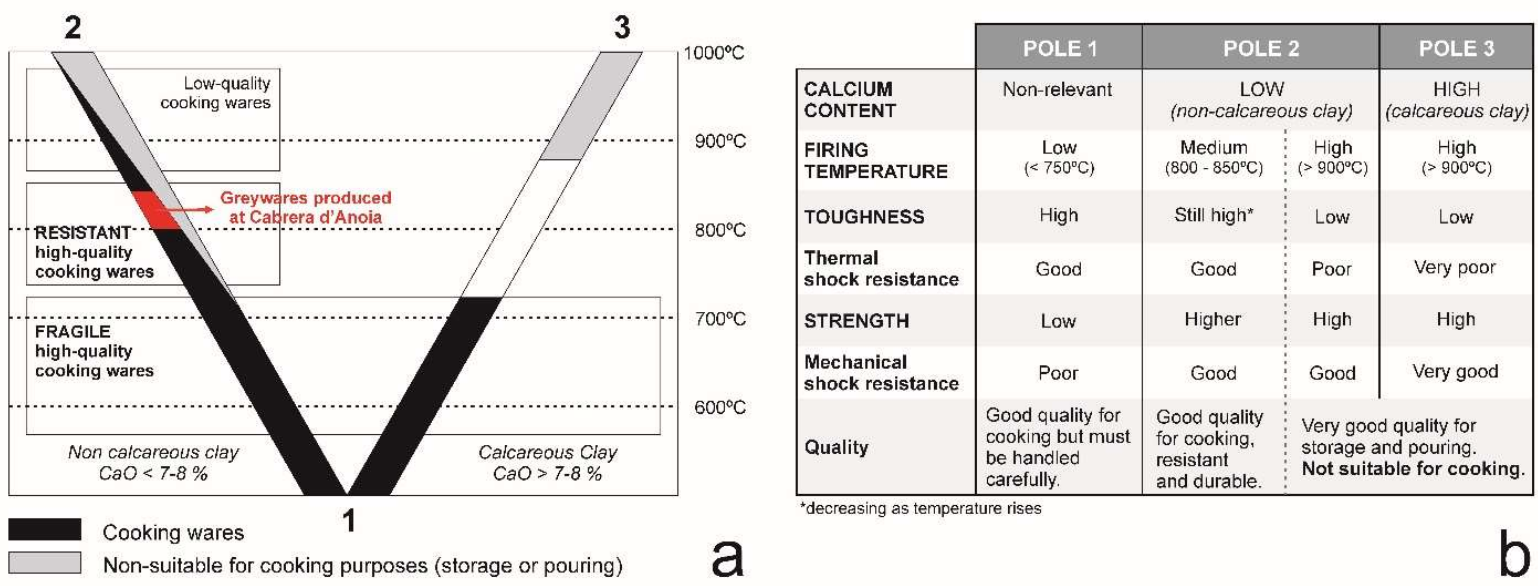

Fig. 6. Relationship between the firing temperature of traditional coarseware pottery, its physical characteristics and suitability for cooking purposes, as determined experimentally by Picon (1995) using calcareous and non-calcareous clay bodies. Redrawn and annotated from Picon (1995: fig. 1: 286).

Turning to the products of the other Catalan greyware workshops of Casampons, Piera and Quart and comparing the firing temperature of these sherds to the pots exported from Cabrera d'Anoia, it appears that different levels of quality control were applied. The wider range of temperatures seen in the sherds that can be traced to these other potting centres may suggest that either they 
were less able to control the firing conditions of their kilns, or alternatively, that the potters were not as concerned about producing cooking vessels with optimised material properties and performance, as they were at Cabrera d'Anoia. Though this interpretation is tentative at this point, due to the small numbers of sherds involved and the absence of analyses on production material from these other kiln sites, it is tempting to propose that it was an important reason behind the success of Cabrera d'Anoia, which exported its products within a radius of $40 \mathrm{~km}$ or more during Medieval times (Travé et al. 2016). Greyware cooking pots were an essential commodity in Medieval Catalonia for many centuries and the different regional production centres distributed their products widely, competing with each other for rural markets (Travé et al. 2016). Given the choice between visually similar utilitarian cooking vessels made by different workshops, it is likely that their functional performance and suitability for their intended purpose would have been a key factor that customers considered when deciding who's product to use. With this in mind, it is obvious that potters would have strived to manufacture the best vessels that they could and exercise stringent quality control before exporting pots for sale, as the present study suggests.

\section{ACKNOWLEDGEMENTS}

This study forms part of a collaborative research project between the Medieval and Postmedieval Archaeology Research Group GRAMP.-UB (2017-SGR-833-GRC) of the University of Barcelona and the Institute of Archaeology, University College London. The authors wish to thank the Pottery Museum of Quart, and especially Mr Joan Vicens Tarré, for providing information and advice. Useful comments and assistance with XRD interpretation was provided by Enrica Bonato and Silvia Amicone, formerly of University College London, and Jaume Buxeda and Marisol Madrid from University of Barcelona.

\section{REFERENCES}

Arnold, D.E., 2000, Does the Standardization of Ceramic Pastes Really Mean Specialization? Journal of Archaeological Method and Theory, 7, 333-375.

Basart, P., 2016, 'Nigra sum'. El process de cuita de la terrissa negra explicat per tres quartencs, in Dossier Rajolers i Terrissers. Gavarres, 30 (eds. Rocas, X., Vicens, J., Basart, P.), 74-75, Editorial Gavarres, Girona.

Cantoni, G., Folch, C., 2015, Excavacions arqueològiques al jaciment de Cal Ticó (Castellnou de Bages): Un centre productor de ceràmica al comtat de Manresa (Segles XI-XII), in Actes del V congrés d'Arqueologia Medieval i Moderna de Catalunya, vol. II, 675-686, Ajuntament de Barcelona/ACRAM, Barcelona.

Cardew, M., 1969, Pioneer Pottery, Longman, London.

Casey, M., Lowe, T., 2011, Archaeological Investigation 710-722 George Street, Haymarket, Sydney, Unpublished report, Casey and Lowe Pty Ltd., Leichhardt (http://www.caseyandlowe.com.au/rept710george.htm)

Cultrone, G., Rodríguez-Navarro, C., Sebastián, E., Cazalla, O., De la Torre, M.J., 2001, Carbonate and Silicate phase reactions during ceramic firing, European Journal of Mineralogy, 13, 621-634. 
Degen, T., Sadki, M., Bron, E., König, U., Nénert, G., 2014, The HighScore suite, Powder Diffraction, 29, 13-18.

Faber, E., Day P.M., Kilikoglou, V., 2009, Fine-Grained Middle Bronze Age Polychrome Ware from Crete: Combining Petrographic and Microstructural Analysis, in Interpreting Silent Artefacts: Petrographic Approaches to Archaeological Ceramics (ed. Quinn, P. S.), 139-156, Archaeopress, Oxford.

Frankel, D., 1994, Color Variation on Prehistoric Cypriot Red Polished Pottery, Journal of Field Archaeology, 21, 205-219.

Fraser, H., 2005, Ceramic Faults and Their Remedies, A. \& C. Black, London.

González, A. (ed.), 1997, Ceràmica catalana. El monument, document, Quaderns científics $i$ tècnics, 9, Diputació de Barcelona, Barcelona.

Kilikoglou. V., Vekinis, G., Maniatis, Y., 1995, Toughening of Ceramic Earthenwares by Quartz Inclusions: An Ancient Art Revisited, Acta Metallurgica et Materialia, 43, 2959-2965.

Kilikoglou, V., Vekinis, G., Maniatis, Y., Day, P. M., 1998, Mechanical Performance of QuartzTempered Ceramics: Part I, Strength and Toughness, Archaeometry, 40, 261-279.

Küpfer, T., Maggetti, M., 1978, Die Terra Sigillata von La Péniche (Vidy/Lausanne), Schweizerische Mineralogische und Petrographische Mitteilungen, 58, 189-212.

Maggetti, M., 1982, Phase analysis and its significance for technology and origin, in Archaeological Ceramics (eds. Olin, J., Franklin, A.), 121-133, Smithsonian Institution Press, Washington D.C.

Maniatis, Y., Tite, M. S., 1975, A scanning electron microscope examination of the bloating of fired clays, Transactions and Journal of the British Ceramic Society, 74, 229-232.

Maritan, L., 2004, Archaeometric study of Etruscan-Padan type pottery from the Veneto region: petrographic, mineralogical and geochemical-physical characterization, European Journal of Mineralogy, 16, 297-307.

Maritan, L., Nodari, L., Mazzoli, C., Milano, A., Russo, U., 2006, Influence of firing conditions on ceramic products: Experimental study on clay rich in organic matter, Applied Clay Science, 31, 1-15.

Maritan, L., Mazzoli, C., Freestone, I., 2007, Modelling changes in mollusc shell internal microstructure during firing: Implications for temperature estimation in shell-bearing pottery, Archaeometry, 49, 529-541.

Müller, N. S., 2016, Mechanical and Thermal Properties, in The Oxford Handbook of Archaeological Ceramic Analysis (ed. Hunt, A.), 321-342, Oxford University Press, Oxford.

Müller, N. S., Kilikoglou, V., Day, P. M., Vekinis, G., 2010, The influence of temper shaper on the mechanical properties of archaeological ceramics, Journal of the European Ceramic Society, 30, 2457-2465.

Müller, N. S., Hein, A., Kilikoglou, V., Day, P. M., 2013, Bronze Age cooking pots: Thermal properties and cooking methods, Préhistoires Méditerranéennes, 4, 1-10.

Nodari, L., Marcuz, E., Maritan, L., Mazzoli, C., Russo, U., 2007, Hematite nucleation and growth in the firing of carbonate-rich clay for pottery production, Journal of the European Ceramic Society, 27, 4665-4673. 
Orton, C. R., 1970, The production of pottery from a Romano-British kiln site: A statistical investigation, World Archaeology, 1, 43-358.

Orton, C., Hughes, M., 2013, Pottery in Archaeology, Cambridge University Press, Cambridge.

Padilla, J. I., 1984, Contribución al estudio de las cerámicas grises catalanas de época medieval: El taller, hornos y producción de Casampons (Berga), in Acta mediaevalia. Annex 2: Ceràmica grisa $i$ terrissa popular de la Catalunya medieval (ed. Riu, M.), 99-143, Universitat de Barcelona, Barcelona.

Padilla, J. I., Álvaro, K., Travé, E., 2008, Un modelo de producción en gruta: el alfar de Cabrera d'Anoia, Barcelona, Munibe Arkeologia-Antropologia, 59, 269-290.

Padilla, J. I., Travé, E., 2010, Adaptación al medio y transformación artesanal: balance actual de las investigaciones acerca del alfar medieval de Cabrera d'Anoia, Boletín de Arqueología Medieval, 14, 259-294.

Peña, J. T., 2007, Roman Pottery in the Archaeological Record, Cambridge University Press, Cambridge.

Peña, J. T., McCallum, M., 2009, The Production and Distribution of Pottery at Pompeii: A Review of the Evidence; Part 2, the Material Basis for Production and Distribution, American Journal of Archaeology, 113, 165-201.

Picon, M., 1995, Grises et grises: quelques réflexions sur les céramiques cuites en mode B, in Actas das las Jornadas de Cerâmica Medieval e Pós-Medieval. Métodos e resultados para o seu estudo (1992), 283-292, Câmara Municipal de Tondela, Porto.

Pollock, S., Steele, C., Pope, M., 1991, Investigations on the Uruk Mound, Abu Salabikh, Iraq, 55, 59-68.

Pradell, T., 1992, Estudi dels processos de reducció en la ceràmica de silicats, Universitat de Barcelona, Barcelona.

Quinn, P. S., 2013, Ceramic Petrography. The interpretation of archaeological pottery and related artefacts in thin section, Archaeopress, Oxford.

Quinn, P. S., Benzonelli, A., 2018, X-Ray Diffraction and Archaeological Materials Analysis, in The SAS Encyclopedia of Archaeological Sciences (ed. López Varela, S. L.). Wiley Blackwell, New Jersey.

Rice, P. M., 1987, Pottery Analysis A sourcebook, The University of Chicago Press, Chicago.

Rye, O. S., 1976, Keeping Your Temper under Control: Materials and the Manufacture of Papuan Pottery, Archaeology and Physical Anthropology in Oceania, 11, 106-137.

Rye, O. S., 1981, Pottery technology: Principles and reconstruction, Taxaracum, Washington D.C.

Sedmale, G., Sperberga, I., Sedmalis, U., 1990, Phase composition and properties of mullite ceramic in high temperature testing, in: Conference proceedings, Symposium Mullite Processing, Structure, and Properties. Bulletin of the American Ceramic Society, 69: 1526-1527.

Stark, B. L., 1985, Archaeological identification of pottery-production locations: Ethnoarchaeological and archaeological data in Mesoamerica, in Decoding prehistoric ceramics (ed. Nelson, B. A.), 158-194, Southern Illinois University Press, Carbondale. 
Stark, M., 2003, Current Issues in Ceramic Ethnoarchaeology, Journal of Archaeological Research, 11, 193-242.

Tite, M. S., Kilikoglou, V., Vekinis, G., 2001, Strength, toughness and thermal shock resistance of ancient ceramics, and their influence on technological choice, Archaeometry, 43, 301-324.

Tite, M. S., Maniatis, Y., 1975a, Examination of ancient pottery using the scanning electron microscope, Nature, 257, 122-123.

Tite, M.S., Maniatis, Y., 1975b, Scanning electron microscopy of fired calcareous clays, Transactions and Journal of the British Ceramic Society, 74, 19-22.

Travé, E., 2017, Los Hornos Medievales y la Cerámica Negra (Medieval Kilns and Greyware Pottery), in Obra negra y alfarería de cocina. XIX Congreso de la Asociación de Ceramología (29 al 31 octubre de 2016), 123-147, Asociación de Ceramología / Ajuntament de Quart / Museu de la Terrissa de Quart, Quart.

Travé, E., 2018, La ceràmica comuna de cuina d'època medieval: Provinença, tecnologia i comerç al camp català. Societat Catalana d'Arqueologia, Barcelona.

Travé, E., Padilla, J. I., 2013, Alfares, hornos y producción de cerámica en la Cataluña medieval y moderna: una reflexión para su estudio, Territorio, sociedad y poder, 8, 105-132.

Travé, E., Quinn, P. S., López, M. D, Padilla, J. I., 2014, One hundred sherds of grey: compositional and technological characterization of medieval greyware pottery production at Cabrera d'Anoia, Catalonia, Spain, Archaeological and Anthropological Sciences, 6, 397-410.

Travé, E., Quinn, P. S., López, M. D., 2016, To the vicinity and beyond! Production, distribution and trade of cooking greywares in Medieval Catalonia, Spain, Archaeological and Anthropological Sciences, 8, 763-778.

Vigil-Escalera, A., Quirós, J. A. (eds.), 2016, La cerámica de la alta edad media en el cuadrante noroeste de la península ibérica (siglos $V$-X). Sistemas de producción, mecanismos de distribución y patrones de consume, Universidad del País Vasco, Bilbao.

Whitney, D. L., Evans, B. W., 2010, Abbreviations for names of rock-forming minerals, American Mineralogist, 95, 185-187.

Yxart, S., 2016, Terrissers a l'antiga, in Dossier Rajolers $i$ Terrissers. Gavarres, 30 (eds. Rocas, X., Vicens, J., Basart, P.), 46-47, Editorial Gavarres, Girona. 